\title{
Atrioventricular canal defect in patients with RASopathies
}

\author{
Maria Cristina Digilio ${ }^{\star}, 1$, Francesca Romana Lepri ${ }^{1}$, Maria Lisa Dentici $^{1}$, Alex Henderson ${ }^{2}$, Anwar Baban ${ }^{1}$, \\ Maria Cristina Roberti ${ }^{1}$, Rossella Capolino ${ }^{1}$, Paolo Versacci ${ }^{3}$, Cecilia Surace ${ }^{1}$, Adriano Angioni ${ }^{1}$, Marco Tartaglia ${ }^{4}$, \\ Bruno Marino ${ }^{3}$ and Bruno Dallapiccola ${ }^{1}$
}

Congenital heart defects affect $60-85 \%$ of patients with RASopathies. We analysed the clinical and molecular characteristics of atrioventricular canal defect in patients with mutations affecting genes coding for proteins with role in the RAS/MAPK pathway. Between 2002 and 2011, 101 patients with cardiac defect and a molecularly confirmed RASopathy were collected. Congenital heart defects within the spectrum of complete or partial (including cleft mitral valve) atrioventricular canal defect were diagnosed in 8/101 (8\%) patients, including seven with a PTPN11 gene mutation, and one single subject with a RAF1 gene mutation. The only recurrent mutation was the missense PTPN11 c.124A $>$ G change (T42A) in PTPN11. Partial atrioventricular canal defect was found in six cases, complete in one, cleft mitral valve in one. In four subjects the defect was associated with other cardiac defects, including subvalvular aortic stenosis, mitral valve anomaly, pulmonary valve stenosis and hypertrophic cardiomyopathy. Maternal segregation of PTPN11 and RAF1 gene mutations occurred in two and one patients, respectively. Congenital heart defects in the affected relatives were discordant in the families with PTPN11 mutations, and concordant in that with RAF1 mutation. In conclusion, our data confirm previous reports indicating that atrioventricular canal defect represents a relatively common feature in Noonan syndrome. Among RASopathies, atrioventricular canal defect was observed to occur with higher prevalence among subjects with PTPN11 mutations, even though this association was not significant possibly because of low statistical power. Familial segregation of atrioventricular canal defect should be considered in the genetic counselling of families with RASopathies.

European Journal of Human Genetics (2013) 21, 200-204; doi:10.1038/ejhg.2012.145; published online 11 July 2012

Keywords: Noonan syndrome; atrioventricular canal defect; RAS/MAPK pathway; PTPN11 gene; RAF1 gene

\section{INTRODUCTION}

Noonan syndrome (NS) and related disorders, including Noonan syndrome-multiple lentigines (NS-ML), Noonan-like with loose anagen hair, Cardio-Facio-Cutaneous and Costello syndromes (the so-called Neuro-Cardio-Facio-Cutaneous syndromes or RASopathies) are causally linked to germ line mutations in a number of genes coding transducers and modulatory proteins participating in the RAS-MAP kinase (MAPK) signaling pathway. ${ }^{1-3}$ Clinical features include dysmorphic features, congenital heart defects (CHDs), postnatal growth retardation, ectodermal and skeletal defects and variable cognitive deficits. CHDs occur in approximately $60-86 \%$ of patients affected by one of these RASopathies, depending on the mutated genes. Pulmonary valve stenosis (PVS) and hypertrophic cardiomyopathy (HCM) are the most common defects displaying a distinct association with the RASopathies. ${ }^{4,5}$ Nevertheless, the spectrum of CHDs in NS syndrome is wider, and the family of atrioventricular canal defects (AVCD) is the third most common heart defect. $^{5-7}$

AVCD includes different anomalies of atrioventricular valves and atrial and ventricular septa. In the complete form, a single common atrioventricular valve and an atrial septal defect (ostium primum) confluent with a posterior ventricular septal defect in the inlet portion of the ventricular septum are found. In the partial form, there are two separate right and left atrioventricular valves with a clefted mitral valve, an atrial septal defect (ostium primum), and no ventricular septal communication. Cleft mitral valve is considered the less severe form of AVCD. ${ }^{8-13}$ A defect of the extracellular matrix has been considered a likely pathogenic mechanism for the defects in the spectrum of AVCD. ${ }^{14,15}$ AVCD is also the most common CHD found in children with Down syndrome and one of the structural heart defects most frequently associated with extracardiac anomalies in the setting of chromosomal and mendelian disorders. ${ }^{16,17}$ Distinct anatomic features are found in AVCD associated with NS. In fact, in general this defect is of the partial type, eventually associated with subaortic stenosis, due to accessory fibrous tissue and/or anomalous insertion of the mitral valve with anomalous papillary muscle of the left ventricle. ${ }^{7,18}$

Recent studies have reported discordant figures for the association between AVCD and RASopathies, which was found only in some series, ${ }^{19-22}$ and not in others. ${ }^{23-28}$ Therefore, the RASopathies are often not considered and probably underestimated among syndromic patients with AVCD. In this study, we analysed clinical, familial and

${ }^{1}$ Department of Medical Genetics, Cytogenetics, Pediatric Cardiology, Bambino Gesù Pediatric Hospital, IRCCS, Rome, Italy; ${ }^{2}$ Northern Genetics Service, Newcastle upon Tyne Hospitals, UK; ${ }^{3}$ Pediatric Cardiology, Department of Pediatrics, Sapienza University, Rome, Italy; ${ }^{4}$ Department of Hematology, Oncology and Molecular Medicine, Istituto Superiore di Sanità, Rome, Italy

*Correspondence: Dr MC Digilio, Department of Medical Genetics, Bambino Gesù Hospital, IRCCS, Piazza S. Onofrio 4, Rome 00165 , Italy. Tel: + 39 06 6859 2227 ; Fax: + 39066859 2004; E-mail: mcristina.digilio@opbg.net

Received 16 January 2012; revised 15 May 2012; accepted 31 May 2012; published online 11 July 2012 
molecular characteristics of AVCD patients with mutations in genes affecting the RAS/MAPK pathway.

\section{SUBJECTS AND METHODS}

From 2002 to 2011, 150 patients with a cardiac anomaly (including structural defects, hypertrophic cardiomyopathy and arrhythmias) associated with other clinical features suggesting the RASopathies' spectrum were evaluated. In all the patients, complete physical examination for major and minor anomalies was carried out by two medical geneticists (MCD, BD). Clinical inclusion criteria of van der Burgt ${ }^{29}$ for NS, Voron et al, ${ }^{30}$ for NS-ML syndrome, Kavamura et $a l^{31}$ for Cardio-Facio-Cutaneous syndrome, Gripp et $a l^{32}$ for Costello syndrome were used. All patients had cardiological assessment, including chest radiograph, electrocardiogram and two-dimensional color Doppler echocardiography.

Genomic DNA was obtained from circulating leucocytes, and the entire coding sequence of PTPN11 gene was screened for mutations in all patients by singlestrand conformation polymorphism analysis or denaturing high-performance liquid chromatography (DHPLC), as previously reported. ${ }^{19,23}$ Fragments with an aberrant migration/elution pattern were sequenced. PTPN11 mutationnegative samples were successively screened for mutations in the coding region of the SOS1, RAF1, KRAS, NRAS, SHOC2, CBL, BRAF, MEK1, MEK2 and HRAS genes by DHPLC analysis and bidirectional direct sequencing.

Patients with AVCD were selected, including those with cleft mitral valve, which is the mildest form of AVCD. ${ }^{6,8,11-13}$ In cardiac classification, the focus was to the spectrum of AVCDs, and the other cardiovascular anomalies were considered as secondary diagnosis. Mutations found in the present series of patients with AVCD/related defects and in published series of AVCD were reviewed and analysed for possible genotype-phenotype correlations. The proportion of patients in the present series with AVCD and mutations in one of the genes of the RAS/MAPK pathway was compared with that of patients displaying other CHDs.

\section{RESULTS}

Pathogenic mutations were found in 101/150 (67\%) patients, including 67/101 (66\%) in PTPN11 gene, 9/101 (9\%) in SOS1, 8/101 (8\%) in $R A F 1,7 / 101(7 \%)$ in BRAF, 5/101 (5\%) in HRAS, 2/101 (2\%) in SHOC2, 1/101 (1\%) each in MEK2, NRAS and CBL. None of the analysed patients had any KRAS gene mutation.

Among the 13 patients exhibiting AVCD or a related heart defect ( $9 \%$ of the total cases), disease causative changes occurred in $8 / 101$
(8\%), indicating similar distribution among mutation-positive and mutation-negative subjects (Fisher's exact probability $=0.51$ ). Seven subjects ( $88 \%$ of the eight mutated cases) had a PTPN11 gene mutation, including six subjects with NS and one with NS-ML. A heterozygous RAF1 gene mutation was found in one NS patient ( $12 \%$ of the eight mutated cases). No pathogenic mutation in any of the other analysed genes was detected in the remaining five patients (Table 1). Although the observed AVCD distribution among subjects with molecularly confirmed RASopathy was suggestive for a higher prevalence of this defect in individuals with a mutated PTPN11 allele, this association did not reach statistical significance (7/67 vs 1/34; Fisher's exact probability $=0.179$ ).

Cardiac anatomy, clinical diagnosis and molecular details of AVCD patients with mutations are summarized in Table 1. Partial AVCD was diagnosed in six patients, complete AVCD and cleft mitral valve in one each. AVCD was found to be associated with an additional cardiac defect found in 4 (57\%) patients, including HCM (two cases) and subvalvular aortic stenosis, PVS, parachute mitral valve in one patient each. Isolated cleft mitral valve was associated with atrial septal defect ostium secondum type in one patient.

Familial segregation of the mutation was documented in $3 / 8(38 \%)$ families, the mutated allele having been inherited by the affected mother in all cases. CHDs in the affected relatives were discordant in two families with PTPN11 gene mutations (PVS, atrial septal defect ostium secundum type), whereas it was concordant in the RAF1 gene family with mutation (cleft mitral valve) (Table 2).

A relatively wide spectrum of mutations was documented in patients with AVCD, the only recurrent mutation being the PTPN11 c.124 A>G (T42A) substitution. Table 3 summarizes known mutations in AVCD patients with any RASopathy, including two patients with AVCD and PTPN11 mutation, ${ }^{22}$ one patient with cleft mitral valve and KRAS mutation, ${ }^{33}$ and one with cleft mitral valve and $B R A F$ mutation. ${ }^{34}$ The patients are counted once, accordingly to the primary diagnosis. The percentage of subjects with AVCD among the patients with molecular diagnosis and CHDs and frequency of the different mutations in the total series of patients with mutations is shown in Supplementary Table 4.

Table 1 Clinical, cardiological and molecular findings in patients with AVCD and any RASopathy

\begin{tabular}{|c|c|c|c|c|c|}
\hline Patient & Sex & Phenotype & Cardiac defect & Exon & Mutation \\
\hline \multicolumn{6}{|l|}{ PTPN11 } \\
\hline 1 & M & Noonan syndrome & Partial AVCD, subvalvular aortic stenosis & 2 & c. $124 \mathrm{~A}>\mathrm{G}(\mathrm{T} 42 \mathrm{~A})$ \\
\hline 2 & $\mathrm{~F}$ & Noonan syndrome & Cleft mitral valve, atrial septal defect (ostium secundum type) & 2 & c. $124 \mathrm{~A}>\mathrm{G}(\mathrm{T} 42 \mathrm{~A})$ \\
\hline 3 & $\mathrm{~F}$ & Noonan syndrome & Partial AVCD & 3 & c. $188 \mathrm{~A}>\mathrm{G}(\mathrm{Y} 63 \mathrm{C})$ \\
\hline 4 & M & Noonan syndrome & Partial AVCD & 3 & c. $214 \mathrm{G}>\mathrm{T}(\mathrm{A} 72 \mathrm{~S})$ \\
\hline 5 & $\mathrm{~F}$ & Noonan syndrome & Partial AVCD, PVS & 8 & c. $923 \mathrm{~A}>\mathrm{G}(\mathrm{N} 308 \mathrm{~S})$ \\
\hline 6 & M & LEOPARD syndrome & Partial AVCD, parachute mitral valve, $\mathrm{HCM}$ & 12 & c. $1403 \mathrm{C}>\mathrm{T}(\mathrm{T} 468 \mathrm{M})$ \\
\hline 7 & $\mathrm{~F}$ & Noonan syndrome & Complete AVCD & 13 & c. $1472 \mathrm{C}>\mathrm{T}(\mathrm{P} 491 \mathrm{~L})$ \\
\hline \multicolumn{6}{|l|}{$R A F 1$} \\
\hline 8 & $\mathrm{~F}$ & Noonan syndrome & Partial AVCD, HCM & 7 & c.781 C>T (P261S) \\
\hline \multicolumn{6}{|c|}{ No mutations } \\
\hline 9 & $\mathrm{~F}$ & Noonan syndrome & Partial AVCD & - & - \\
\hline 10 & M & Noonan syndrome & Partial AVCD & - & - \\
\hline 11 & M & Noonan syndrome & Partial AVCD, subvalvular aortic stenosis & - & - \\
\hline 12 & $\mathrm{~F}$ & Noonan syndrome & Partial AVCD, double mitral orifice, cor tiatriatum- & - & - \\
\hline 13 & $\mathrm{~F}$ & Noonan syndrome & Partial AVCD & - & - \\
\hline
\end{tabular}

Abbreviations: AVCD, atrioventricular canal defect; F, female; HCM, hypertrophic cardiomyopathy; M, male. 


\section{DISCUSSION}

AVCD is the third most common CHD in NS, after PVS and $\mathrm{HCM},{ }^{7,21}$ and it has been also documented to occur in NS-ML

Table 2 Clinical and molecular characteristics of families segregating mutations of the RAS/MAPK pathway

\begin{tabular}{|c|c|c|c|c|c|}
\hline Family & Sex & Phenotype & $\begin{array}{l}\text { Mutated } \\
\text { gene }\end{array}$ & Mutation & Cardiac anomaly \\
\hline \multicolumn{6}{|l|}{ Family 1} \\
\hline $\begin{array}{l}\text { Proband (patient } \\
5\end{array}$ & $\mathrm{~F}$ & NS & PTPN11 & N308S & partial AVCD, PVS \\
\hline in Table 1) & & & & & \\
\hline Brother & M & NS & PTPN11 & N308S & PVS \\
\hline Mother & $\mathrm{F}$ & NS & PTPN11 & N308S & Normal heart \\
\hline \multicolumn{6}{|l|}{ Family 2} \\
\hline $\begin{array}{l}\text { Proband (patient } \\
7 \\
\text { in Table 1) }\end{array}$ & $\mathrm{F}$ & NS & PTPN11 & P491L & complete AVCD \\
\hline Brother & M & NS & PTPN11 & P491L & $\begin{array}{l}\text { ASD ostium } \\
\text { secundum }\end{array}$ \\
\hline Mother & $\mathrm{F}$ & NS & PTPN11 & P491L & PVS \\
\hline \multicolumn{6}{|l|}{ Family 3} \\
\hline $\begin{array}{l}\text { Proband (patient } \\
8 \\
\text { in Table 1) }\end{array}$ & $\mathrm{F}$ & NS & RAF1 & P261S & partial AVCD, HCM \\
\hline Mother & $\mathrm{F}$ & NS & RAF1 & P261S & cleft MV, HCM \\
\hline
\end{tabular}

Abbreviations: ASD, atrial septal defect; $A V C D$, atrioventricular canal defect; $F$, female; $\mathrm{HCM}$ hypertrophic cardiomyopathy; M, male; NS, Noonan syndrome; MV, mitral valve; PVS, pulmonary valve stenosis. syndrome. ${ }^{19,35}$ The first clinical series reported a figure of 15\% AVCD in NS..$^{5-7,16,36,37}$ In more recent molecular studies, however, AVCD was described only in a few patients, arguing that it might represent a relatively rare complication in RASopathies. It is likely that this discrepancy could be simply a matter of misdiagnosis, as shown by personal experience based on cases originally designated as 'non-Down AVCD syndrome', displaying 'peculiar facial appearance with hypertelorism, epicanthus, depressed nasal bridge and ear anomalies,' ${ }^{38}$ which later were proved to be affected by NS. Actually, the fact that the association between NS and AVCD is not rare is also evidenced by previous clinical observations from our group, reporting that the prevalence of NS in a consecutive series of patients with non-Down AVCD and situs solitus was corresponding to $11 \%$ (22/203 cases). ${ }^{16}$

In the present series, AVCD was diagnosed in $8 \%$ of the patients with a molecularly confirmed RASopathy. A mutation in the known genes can be detected in the $62 \%$ of patients with AVCD and clinical features consistent with any RASopathy. The majority of these patients were heterozygous for a pathogenic PTPN11 mutation, a single familial case presenting with a RAF1 mutation (Table 1). Although further studies are required to formally confirm such a genotype-phenotype correlation, published data appear also to support this association, ${ }^{22}$ with single reports of cleft mitral valve in individuals with KRAS $^{33}$ and BRAF ${ }^{34}$ mutations.

Mutations in unknown genes of the RAS/MAPK pathway or a clinical misdiagnosis could account for the AVCD syndromic patients in which no pathogenic change was detected in any of the 11 screened genes.

A relatively wide spectrum of PTPN11 mutations were documented in the present cohort of subjects with AVCD, the only recurrent mutation being c.124 A>G (T42A), which was found in two patients with AVCD, and with cleft mitral valve and atrial septal ostium secundum type, respectively (Table 1). Interestingly, a missense change affecting

Table 3 CHDs associated with mutations found in AVCD patients with RASopathies

\begin{tabular}{|c|c|c|c|c|c|c|c|c|c|}
\hline Gene & Mutation & $\begin{array}{l}\text { Complete or } \\
\text { partial AVCD } \\
\text { reviewed }\end{array}$ & Cleft MV & PVS & $A S D$ & HCM & $V S D$ & $\begin{array}{l}\text { Total } \\
\text { patients }\end{array}$ & References \\
\hline \multicolumn{10}{|c|}{ PTPN11 } \\
\hline & $\mathrm{T} 42 \mathrm{~A}$ & $\begin{array}{l}1(+ \\
\text { SubAoSt) }\end{array}$ & $\begin{array}{l}1 \\
(+\mathrm{ASD}, \mathrm{HCM})\end{array}$ & & $\begin{array}{l}3(1+\text { IVC and SVC } \\
\text { anomaly }\end{array}$ & & & 5 & Present series, $21,48,49$ \\
\hline & L43F & 1 & & & & & & 1 & 39 \\
\hline & $\begin{array}{l}\text { Y63C } \\
\text { A72S }\end{array}$ & & & $\begin{array}{l}6 \\
1(+A S D)\end{array}$ & 2 & & & $\begin{array}{l}9 \\
2\end{array}$ & $\begin{array}{l}\text { Present series, 21,50-52 } \\
\text { Personal series }\end{array}$ \\
\hline & N308S & $1(+$ PVS $)$ & & $\begin{array}{l}1(+A S D) \\
10 \\
(1+A S D)\end{array}$ & $1(+\mathrm{PVS})$ & & 1 & 13 & Present series, $21,37,52,53$ \\
\hline & $\begin{array}{l}\text { Exon } 8 \text { (muta- } \\
\text { tion } \\
\text { unspecified) }\end{array}$ & 1 & & & & & & 1 & 22 \\
\hline & T468M & $\stackrel{1}{(+\mathrm{HCM}, \mathrm{PMV})}$ & & 3 & & $\begin{array}{l}9(2+\text { MVA }) \\
(1+\text { SubAoSt }) \\
(1+\text { PVS })\end{array}$ & & 13 & $\begin{array}{l}\text { Present series, } \\
19,21,35,54-56\end{array}$ \\
\hline & P491L & 1 & & 1 & 1 & & & 3 & Present series \\
\hline \multicolumn{10}{|c|}{$R A F 1$} \\
\hline & P261S & $1(+\mathrm{HCM})$ & $1(+\mathrm{HCM})$ & 1 & & $\begin{array}{l}7 \text { (1+AoSt }) \\
(1+\text { ASD }) \\
(1+\text { ASD,VSD })\end{array}$ & & 10 & Present series, 47,57 \\
\hline \multicolumn{10}{|c|}{$B R A F$} \\
\hline KRAS & Q257R & & 1 & 1 & & $\begin{array}{l}1 \\
2(+ \\
\text { PVS,ASD }) \\
1(+ \text { PVS })\end{array}$ & & 6 & $32,34,58$ \\
\hline & V14I & & 1 & & & & & 1 & 33 \\
\hline
\end{tabular}

Abbreviations: AVCD, atrioventricular canal defect; MV, mitral valve; PVS, pulmonary valve stenosis; ASD, atrial septal defect; HCM, hypertrophic cardiomyopathy; VSD, ventricular septal defect; SubAoSt, subaortic stenosis; IVC, inferior vena cava; SVC, superior vena cava; PMV, parachute mitral valve; MVA, mitral valve anomaly; AoSt, aortic stenosis.

aThe patients are counted once, accordingly to the primary diagnosis. 

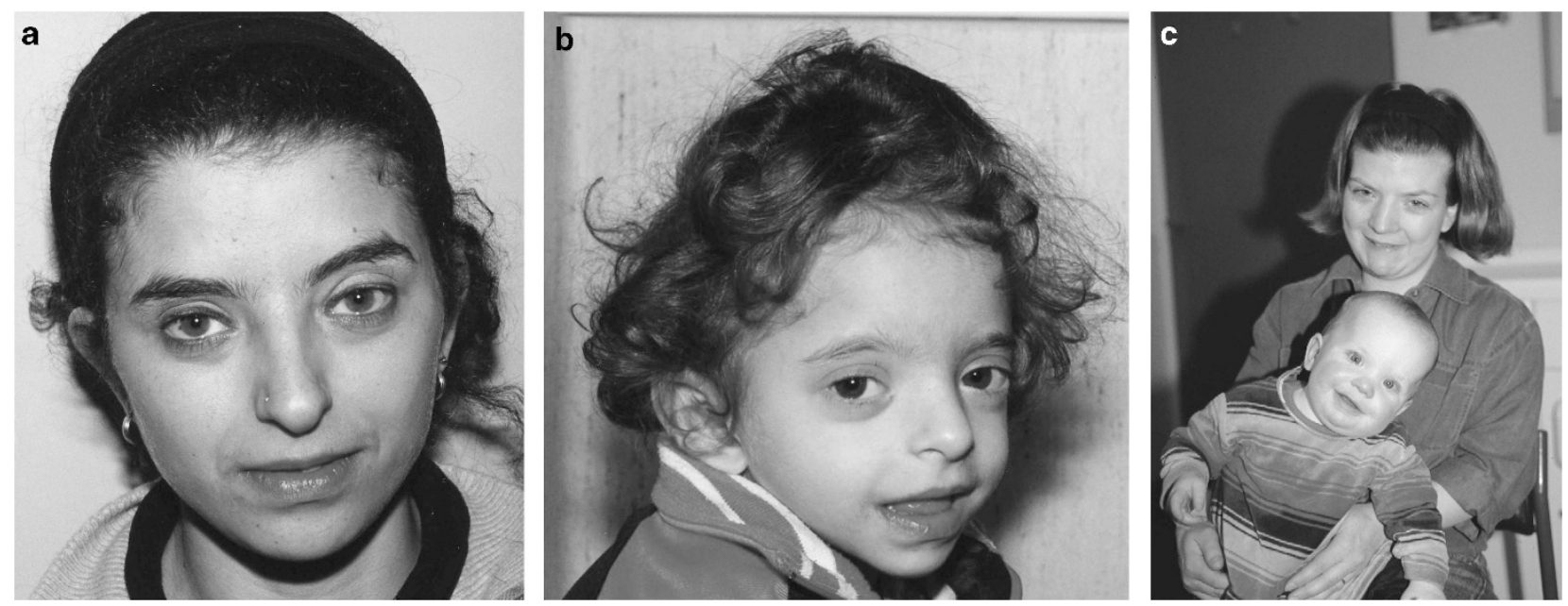

Figure 1 Facial appearance of affected mother and daughter from families $2(\mathbf{a}, \mathbf{b})$ and 3 (c).

the adjacent leucine residue (L43F) mutation was reported previously in a subject with an apparently nonsyndromic complete AVCD. ${ }^{39}$ This observation suggests that mutations predicting to enhance SHP2's binding to signiling partners might represent a functional hot spot for this anatomic defect. ${ }^{40}$ Additionally, Krenz et al, ${ }^{41}$ have shown that PTPN11 Q79R mutation in exon 3 affects cell proliferation during endocardial cushion development in chick embryos, by increasing signaling via the Ras-MAPK pathway. Based on personal experience, we infer that mutations affecting the PTPN11 N-SH2 domain are in general associated with sporadic AVCD without additional CHDs, whereas familial RASopathies with AVCD are mostly associated with mutations in the PTP-domain, specifically involving exons 8 and 13.

We documented the occurrence of intrafamilial variability of the CHD phenotype, with affected relatives displaying either PVS, atrial septal defect ostium secundum type or a normal heart (Table 2) (see Figures $1 \mathrm{a}$ and $\mathrm{b}$ ). This observation suggests that AVCD-related mutations can result in a wider spectrum of CHDs, and that this issue should be considered in the genetic counseling of familial NS. Concordant segregation of CHDs, however, was also found. In particular, isolated cleft mitral valve was diagnosed in the mother of a child with AVCD, both carrying the RAF1 P261S mutation (see Figure 1c). HCM was also found in both the cases.

Anatomic peculiarities of AVCD previously reported in patients with NS include the partial-type defect, and the association with subaortic stenosis. ${ }^{7,18,42}$ The structural abnormalities causing congenital subaortic stenosis consist of accessory fibrous tissue and/ or anomalous insertion of the mitral valve and anomalous left ventricle papillary muscle. Anomalies of mitral valve leaflets and subvalvular mitral apparatus reported in patients with NS are similar to those found in subjects with $\mathrm{HCM} .{ }^{43-45}$ This is not surprising, considering that myocardial disarray and cardiac hypertrophy are common in NS. Therefore, a perturbed developmental mechanism of left ventricular myocardium and mitral valve should be contemplated in the pathogenesis of CHDs in these patients. Accordingly, mitral valve anomalies associated with AVCD in NS could result from the same pathogenic mechanism responsible for mitral anomalies in HCM. The coexistence of both AVCD and HCM in the same patient affected by RASopathy can lead to the speculation that a defect of the extracellular matrix, known to be pathogenetically associated with AVCD, could be linked also to HCM. Additionally, the association of subvalvular aortic stenosis with HCM may be an aggravating factor in these patients, as it may change the geometry of the outflow tract and promote the development of fibrous abstruction together with the usual shape of the outflow tract in AVCD.

Partial AVCD was the most common type in the present patients. Additional heart defects included subaortic stenosis, HCM, parachute mitral valve and PVS (Table 1). Previous attempts to correlate CHDs and mutations in the RAS/ MAPK pathway have identified possible hot spots for PVS, HCM and atrial septal defects. ${ }^{21,46}$ In the present study, although the numbers of patients are low, we found a somewhat distinct association between AVCD with HCM and PTPN11 T468M and RAF1 P261S mutations, which had been previously related to HCM. For example, PTPN11 T468M mutation was reported in NS-ML patients with $\mathrm{HCM},{ }^{19}$ whereas the prevalence of HCM appeared significantly higher in NS patients carrying RAF1 mutations clustering around Ser259 and Ser612. ${ }^{47}$ Our patient with AVCD and PVS was heterozygous for PTPN11 N308S mutation, previously reported in NS with PVS. ${ }^{21,23}$

The echocardiographic follow-up of patients with mutations linked to HCM is highly recommended. In fact, our patient with NS-ML and PTPN11 Thr468Met mutation developed HCM in childhood, soon after the onset of multiple lentigines. In addition, Pandit et al, ${ }^{47}$ reported on a 6-year-old girl with RAF1 P261S mutation and a normal heart, while the same mutation in her mother was associated with HCM with an onset in the young adult age.

In conclusion, AVCD is a part of the phenotypic spectrum of CHDs found in patients with RASopathies, in particular those caused by PTPN11 and RAF1 mutations. Clinical features of NS should be investigated in syndromic patients with AVCD. In general, the spectrum of molecular changes in these patients is rather heterogeneous, the only recurrent mutation being PTPN11 c.124A $>\mathrm{G}$ (T42A). Both partial AVCD and left-sided obstructions, PVS and HCM, must be regarded as markers of the RASopathies in which the anatomic type of CHDs appears at time mutation-specific. Finally, the possibility of AVCD familial segregation should be discussed in the genetic counselling of RASopathies.

\section{CONFLICT OF INTEREST}

The authors declare no conflict of interest.

\section{ACKNOWLEDGEMENTS}

This work was funded in part by grants from Telethon-Italy (GGP10020), ERA-Net for research programs on rare diseases 2009 (NSEuroNet) and Programma di collaborazione Italia-USA 2010 (11US/10) to MT. 
1 Schubbert S, Bollag G, Shannon K: Deregulated Ras signalling in developmental disorders: new tricks for an old dog. Curr Opin Genet Dev 2007; 17: 15-22.

2 Tidyman WE, Rauen KA: The RASopathies: developmental syndromes of Ras/MAPK pathway dysregulation. Curr Opin Genet Dev 2009; 19: 230-236.

3 Tartaglia M, Zampino G, Gelb BD.: Noonan syndrome: Clinical aspects and molecular pathogenesis. Mol Syndromol 2010; 1: 2-26.

4 van der Hauwaert LG, Fryns JP, Dumoulin M, Logghe N: Cardiovascular malformations in Turner's and Noonan's syndrome. Br Heart J 1978; 40: 500-509.

5 Burch M, Sharland M, Shinebourne E, Smith G, Patton M, McKenna W: Cardiologic abnormalities in Noonan syndrome: phenotypic diagnosis and echocardiographic assessment in 118 patients. J Am Coll Cardiol 1993; 22: 1189-1192.

6 Nora JJ, Lortscher RH, Spangler RD: Echocardiographic studies of left ventricular disease in Ullrich-Noonan syndrome. Am J Dis Child 1975; 129: 1417-1420.

7 Marino B, Digilio MC, Toscano A, Giannotti A, Dallapiccola B: Congenital heart diseases in children with Noonan syndrome: an expanded cardiac spectrum with high prevalence of atrioventricular canal. J Pediatr 1999; 135: 703-706.

8 Sumner RG, Phillips JH, Jacoby Jr WJ, Tucker DH: Forme fruste of endocardial cushion defect. Am J Med Sci 1967; 254: 266-283.

9 Nora JJ: Etiologic factors in congenital heart disease. Pediatr Clin North Am 1971; 18 1059-1074.

10 DiSegni E, Pierpont MEM, Bass JL, Kaplinsky E: Two dimensional echocardiography in detection of endocardial cushion defect in families. Am J Cardiol 1985; 55 1649-1652.

11 Digilio MC, Marino B, Cicini MP, Giannotti A, Formigari R, Dallapiccola B: Risk of congenital heart defects in relatives of patients with atrioventricular canal. Am J Dis Child 1993; 147: 1295-1297.

12 Digilio MC, Marino B, Giannotti A, Dallapiccola B: Familial atrioventricular septal defect: possibile genetic mechanism. Br Heart J 1994; 72: 301.

13 Cousineau AJ, Lauer RM, Pierpont ME et al: Linkage analysis of autosomal dominan atrioventricular canal defects: exclusion of chromosome 21. Hum Genet 1994; 93 103-108.

14 Clark EB: Mechanisms in the pathogenesis of congenital heart defects; in Pierpont MEM, Moller JH (eds): Genetics of Cardiovascular Disease. Martinus-Nijoff Publishing: Boston, 1986; pp 3-11.

15 Clark EB: Pathogenetic mechanism of congenital cardiovascular malformations revisited. Semin Perinatal 1996; 29: 465-472.

16 Digilio MC, Marino B, Toscano A, Giannotti A, Dallapiccola B: Atrioventricular cana defect without Down sindrome: a heterogeneous malformation. Am J Med Genet 1999, 85: 140-146.

17 Marino B, Digilio MC: Congenital heart disease and genetic syndromes: specific correlation between cardiac phenotype and genotype. Cardiovasc Pathol 2000; 9 303-315.

18 Marino B, Gagliardi MG, Digilio MC et al: Noonan syndrome: structural abnormalities of the mitral valve causing subaortic obstruction. Eur J Pediatr 1995; 154: 949-952.

19 Digilio MC, Conti E, Sarkozy A et al: Grouping the multiple-lentigines/LEOPARD and Noonan syndromes on the PTPN1 1 gene. Am J Hum Genet 2002; 71: 389-394.

20 Digilio MC, Lepri F, Baban A et al: RASopathies: Clinical diagnosis in the first year of life. Mol Syndromol 2010; 1: 282-289.

21 Sarkozy A, Conti E, Seripa D et al: Correlation between PTPN11 gene mutations and congenital heart defects in Noonan and LEOPARD syndromes. J Med Genet 2003; 40 704-708.

22 Sznajer Y, Keren B, Baumann C et al: The spectrum of cardiac anomalies in Noonan syndrome as a result of mutations in the PTPN11 gene. Pediatrics 2007; 119: e1325-e1331.

23 Tartaglia M, Mehler EL, Goldberg R et al: PTPN11 mutations in Noonan syndrome: Molecular spectrum, genotype-phenotype correlation, and phenotypic heterogeneity. Am J Hum Genet 2002; 70: 1555-1563.

24 Musante L, Kehl HG, Majewski $\mathrm{F}$ et al: Spectrum of mutations in PTPN11 and genotype-phenotype correlation in 96 patients with Noonan syndrome and five patients with cardio-facio-cutaneous syndrome. Eur J Hum Genet 2003; 11: 201-206.

25 Zenker M, Buheitel G, Rauch R et al: Genotype-phenotype correlations in Noonan syndrome. J Pediatr 2004; 144: 368-374.

26 Jongmans M, Otten B, Nordam K, van der Burgt I: Genetics and variation in phenotype in Noonan syndrome. Horm Res 2004; 62(Suppl 3): 56-59.

27 Bertola DR, Pereira AC, Albano LM, De Oliveira PS, Kim CA, Krieger JE: PTPN11 gene analysis in 74 Brazilian patients with Noonan syndrome or Noonan-like phenotype. Genet Test 2006; 10: 186-191.

28 Lin AE, Alexander ME, Colan SD et al: Clinical, pathological, and molecular analyses of cardiovascular abnormalities in Costello syndrome: a Ras/MAPK pathway syndrome. Am J Med Genet 2011; 155A: 486-507.

29 van der Burgt I: Noonan syndrome. Orphanet J Rare Dis 2007; 2: 4.

30 Voron DA, Hatfield HH, Kalkhoff RK: Multiple lentigines syndrome. Case report and review of the literature. Am J Med 1976; 60: 447-456.

31 Kavamura NI, Peres CA, Alchhorne MMA, Brunoni D: CFC index for the diagnosis of cardiofaciocutaneous syndrome. Am J Med Genet 2002; 112: 12-16.
32 Gripp KW, Lin AE, Nicholson L et al: Further delineation of the phenotype resulting from $B R A F$ or MEK1 germline mutations helps differentiate Cardiofacio-cutaneous syndrome from Costello syndrome. Am J Med Genet 2007; 143A 1472-1480.

33 Schubbert S, Zenker M, Rowe SL et al: Germline KRAS mutations cause Noonan syndrome. Nat Genet 2006; 38: 331-336.

34 Neumann TE, Allanson J, Kavamura I et al: Multiple giant cell lesions in patients with Noonan syndrome and cardio-facio-cutaneous syndrome. Eur J Hum Genet 2009; 17: 420-425.

35 Sarkozy A, Conti E, Digilio MC et al: Clinical and molecular analysis of 30 patients with multiple lentigines LEOPARD sindrome. J Med Genet 2004; 41: e68.

36 Starr A, Hovaguimian H: Surgical repair of subaortic stenosis in atrioventricular cana defects. J Thorac Cardiovasc Surg 1994; 108: 373-376.

37 Feit LR, Hansen K, Oyer CE, Werner JC: Unusual combination of congenital heart defects in an infant with Noonan syndrome. Pediatr Cardiol 1995; 16 95-99.

38 Marino B, Guccione P, Marcelletti C, Dallapiccola B: Atrioventricular canal without Down syndrome associated with additional cardiac and noncardiac anomalies. Am J Dis Child 1990; 144: 752

39 Weismann CG, Hager A, Kaemmerer $\mathrm{H}$ et al: PTPN11 mutations play a minor role in isolated congenital heart disease. Am J Med Genet 2005; 136A: 146-151.

40 Martinelli S, Torreri $\mathrm{P}$, Tinti $\mathrm{M}$ et al: Diverse driving forces underlie the invariant occurrence of the T42A, E139D, I282V and T468M SHP2 amino acid substitutions causing Noonan and LEOPARD syndromes. Hum Mol Genet 2008; 17: 2018-2029.

41 Krenz M, Yutzey KE, Robbins J: Noonan syndrome mutation Q79R in Shp2 increases proliferation of valve primordia mesenchymal cells via extracellular signal-regulated kinase 1/2 signaling. Circ Res 2005; 97: 813-820.

42 Gow RM, Freedom RM, Williams WG, Trusler GA, Rowe RD: Coarctation of the aorta or subaortic stenosis with atrioventricular septal defect. Am J Cardiol 1984; 53 1421-1428.

43 Klues HG, Roberts WC, Maron BJ: Anomalous insertion of papillary muscle directly into anterior mitral leaflet in hypertrophic cardiomyopathy. Significance in producing left ventricular outflow obstruction. Circulation 1991; 84: 1188-1197.

44 Klues HG, Maron BJ, Dollar AL, Roberts WC: Diversity of structural mitral valve alterations in hypertrophic cardiomyopathy. Circulation 1992; 85: 1651-1660.

45 Maron MS, Olivotto I, Harrigan C et al: Mitral valve abnormalities identified by cardiovascular magnetic resonance represent a primary phenotypic expression of hypertrophic cardiomyopahy. Circulation 2011; 124: 40-47.

46 Digilio MC, Marino B, Sarkozy A, Versacci P, Dallapiccola B: The heart in Ras-MAPK pathway disorders; in Zenker M (ed): Noonan Syndrome and Related Disorders. Monographs on Human Genetics. Karger: Basel, 2009; vol 17, pp 109-118.

47 Pandit B, Sarkozy A, Pennacchio LA et al: Gain-of-function RAF1 mutations cause Noonan syndrome and LEOPARD syndromes with hypertrophic cardiomyopathy. Nat Genet 2007; 8: 1007-1012.

48 Lee ST, Ki CS, Lee HJ: Mutation analysis of the genes involved in the Ras-mitogenactivated protein kinase (MAPK) pathway in Korean patients with Noonan syndrome. Clin Genet 2007; 72: 150-155.

49 Shaw AC, Kalidas K, Crosby AH, Jeffery S, Patton MA: The natural history of Noonan syndrome: a long-term follow-up study. Arch Dis Child 2007; 92: 128-132.

50 Kosaki K, Suzuki T, Muroya K et al: PTPN11 (protein-tyrosine phosphatase, nonreceptor-type 11) mutations in seven Japanese patients with Noonan syndrome. J Clin Endocrinol Metab 2002; 87: 3529-3533.

51 Maheshwari M, Belmont J, Fernbach S et al: PTPN11 mutations in Noonan syndrome type I: detection of recurrent mutations in exons 3 and 13. Hum Mut 2002; 20 : 298-304.

52 Becker $\mathrm{K}$, Hughes $\mathrm{H}$, Howard $\mathrm{K}$ et al: Early fetal death associated with compound heterozygosity for Noonan syndrome-causative PTPN11 mutations. Am J Med Genet 2007; 143A: 1249-1252.

53 Brasil AS, Malaquias AC, Wanderley LT et al: Co-occurring PTPN11 and SOS1 gene mutations in Noonan syndrome: does this predict a more severe phenotype? Arq Bras Endocrinol Metabol 2010; 54: 717-722.

54 Digilio MC, Capolino R, Marino B, Sarkozy A, Dallapiccola B.: Congenital intrahepatic portosystemic venous shunt: An unusual feature in LEOPARD syndrome and in Neurofibromatosis type 1. Am J Med Genet 2005; 134A: 457-458.

55 Limongelli G, Pacileo G, Marino B et al: Prevalence and clinical significance of cardiovascular abnormalities in patients with the LEOPARD syndrome. Am J Cardiol 2007; 100: 736-741

56 Limongelli G, Sarkozy A, Pacileo G et al: Genotype-phenotype analysis and natura history of left ventricular hypertrophy in LEOPARD syndrome. Am J Med Genet 2008, 146A: 620-628.

57 Razzaque MA, Nishizawa T, Komoike $Y$ et al: Germline gain-of-function mutations in RAF1 cause Noonan syndrome. Nat Genet 2007; 39: 1013-1017.

58 Sarkozy A, Carta C, Moretti S et al: Germline BRAF mutations in Noonan, LEOPARD, and cardiofaciocutaneous syndromes: molecular diversity and associated phenotypic spectrum. Hum Mutat 2009; 30: 695-702.

Supplementary Information accompanies the paper on European Journal of Human Genetics website (http://www.nature.com/ejhg) 